\title{
Problemy przekładu podmiotów zaimkowych w aktach prawnych na język polski
}

Problems in translation of pronoun subjects in legal acts into Polish

\author{
Jan ILUK \\ Uniwersytet Śląski w Katowicach/ University of Silesia in Katowice \\ E-mail: jan.iluk@us.edu.pl, \\ Lukasz ILUK \\ Wyższa Szkoła Finansów i Prawa w Bielsku-Białej/ Bielsko-Biała School of Finances \\ and Law \\ E-mail: lukasz@iluk.katowice.pl,
}

\begin{abstract}
In many languages principles in use of pronoun subjects are similar, however in legal texts there are more specific restrictions. They can impact on the chosen translation strategy. To analyse this problem three examples of translation of German constitution and Swiss constitution into Polish and another two examples of translation of the Polish constitution into German were used. The author paid special attention to the equivalence issues. At the end of the paper possibilities of adequate pronoun subjects translation were pondered.
\end{abstract}

Keywords: translation of constitution, law language, pronoun subjects in legal texts, translations problems

\section{Wstęp}

W wypowiedziach normatywnych podmiot może być wyrażany rzeczownikiem lub zaimkiem anaforycznym. Stylistyczne zasady ich stosowania w różnych językach są podobne, ale w przypadku tekstów prawnych występują wyraźne różnice interlingwalne. Dotyczą one zasad użycia podmiotów zaimkowych, ich szyku w zdaniu oraz frekwencji. Nie pozostają one bez wpływu na wybór strategii przekładu. Bez ich uwzględnienia dokonywane przekłady cechuje przypadkowość, arbitralność, niekonsekwencja w podejmowanych rozwiązaniach translacyjnych, stylistyczna niepoprawność w języku docelowego porządku prawnego oraz niedopuszczalne zmiany treści. 
Do analizy podjętego problemu wykorzystano trzy przekłady niemieckiej Ustawy Zasadniczej ${ }^{1}$ i Konstytucji Szwajcarii na język polski oraz dwóch tłumaczeń Konstytucji Rzeczpospolitej Polskiej ${ }^{2}$ na język niemiecki. Celem analizy jest ukazanie specyfiki użycia podmiotów zaimkowych w tekstach prawnych, ustalenie występujących różnic interlingwalnych i ich wpływu na wybór formy rozwiązania translacyjnego. $\mathrm{Na}$ tym tle w końcowym rozdziale zostaną przedstawione propozycje przekładu uwzględniające uzus stylistyczno-tekstowy w ww. porządkach prawnych.

\section{Funkcja i forma podmiotu w aktach prawnych}

W tekstach prawnych podmiot określa adresata normy lub osobę (instytucję) przyjmującą czyjeś obowiązki. Rolę podmiotu może też pełnić nazwa czynności będąca przedmiotem regulacji (zob. A. Malinowski 2012: 99). Jedną z charakterystycznych cech składni aktów prawnych jest sposób wyrażania podmiotu. Z badań Mikołajczaka wynika, że $88,6 \%$ podmiotów gramatycznych w polskich ustawach ma formę rzeczownikową (zob. S. Mikołajczak 1994: 44). Jest on powtarzany nie tylko w ramach jednego artykułu, lecz nawet w bezpośrednio sąsiadujących zdaniach w obrębie tego samego punktu. Powtarzanie rzeczowników w bliskim sąsiedztwie w tekstach prawnych, niekoniecznie w funkcji podmiotu, może być odczytane jako odstępstwo od normy stylistycznej, ale jest konsekwencją stosowania § 10 Zasad techniki prawodawczej (ZTP) ${ }^{3}$. Zgodnie z treścią tego przepisu unika się synonimów, które - jak wiadomo - w tekstach prawnych mogłyby być przyczyną trudności interpretacyjnych. Por. art. 116 Konstytucji RP (KRP):

1. Sejm decyduje w imieniu Rzeczypospolitej Polskiej o stanie wojny i o zawarciu pokoju.

2. Sejm może podjąć uchwałę o stanie wojny jedynie w razie zbrojnej napaści na terytorium Rzeczypospolitej Polskiej lub gdy z umów mi ędzynarodowych wynika zobowiązanie do wspólnej obrony przeciwko agresji. Jeżeli Sejm nie może się zebrać na posiedzenie, o stanie wojny postanawia Prezydent Rzeczypospolitej ${ }^{4}$.

Analogiczne zasady obowiązują w ustawodawstwie niemieckim. Por. art 55 GG:

(1) Der Bundespräsident darf weder der Regierung noch einer gesetzgebenden Körperschaft des Bundes oder eines Landes angehören.

\footnotetext{
${ }^{1}$ Ustawa Zasadnicza Republiki Federalnej Niemiec z dnia 23 maja 1949. Tłumaczenie Bogusław Banaszak i Agnieszka Malicka. Cyt. UZ/B\&M; Ustawa Zasadnicza dla Republiki Federalnej Niemiec. Tekst bez komentarza. Tłumaczenie Aleksander-Marek Sadowski. Cyt. UZ/Sa; Ustawa Zasadnicza Republiki Federalnej Niemiec z 23 maja 1949 zmieniona w dniu 29 lipca 2009 r. Tłumaczenie z języka niemieckiego Ewa Schwierskott-Matheson. Cyt. UZ/Sch.

${ }^{2}$ Verfassung der Republik Polen vom 2. April 1997. Tłumaczenie Ewa Schwierskott. Cyt. VRP/Sch. Verfassung der Republik Polen vom 2. April 1997. Tłumaczenie Ewa Misior. Cyt. VRP/M.

${ }^{3} \S 10$. ZTP: Do oznaczenie jednakowych pojęć używa się jednakowych określeń, a różnych pojęć nie oznacza się tymi samymi określeniami.

${ }^{4}$ Wytłuszczenia w cytowanych przepisach mają ułatwić identyfikację omawianych członów.
} 
(2) Der Bundespräsident darf kein anderes besoldetes Amt, kein Gewerbe und keinen Beruf ausüben und weder der Leitung noch dem Aufsichtsrate eines auf Erwerb gerichteten Unternehmens angehören.

Inaczej jest w legislacji szwajcarskiej. W federacyjnych i kantonalnych zasadach techniki prawodawczej traktuje się artykuł wzgl. paragraf jako gramatyczną jedność. $\mathrm{W}$ jego ramach i tylko w jego ramach podmioty odnoszące się do wcześniej wyrażonego podmiotu rzeczownikowego muszą być wyrażone zaimkiem ${ }^{5}$. Jest to również motywowane wymogami dotyczącymi struktury artykułu. Zgodnie z nimi artykuł w przepisach szwajcarskich powinien składać się maksymalnie z trzech ustępów. Ustęp ma mieć formę jednego zdania, które ma wyrażać jedną normę. Zdanie ma mieć tzw. szyk prosty, czyli w kolejności podmiot - orzeczenie - dopełnienie (Gesetzgebungsleitfaden, 2007, Ziffer 8235 (888), s. 359 i Richtlinien Zürich, 2005, s. 55, pkt. $181)^{6}$.

Por. art. 70 Konstytucji Kantonu Zurych:

1. Der Regierungsrat leitet die kantonale Verwaltung und bestimmt im Rahmen des Gesetzes ihre Organisation.

2. Er sorgt dafür, dass die Verwaltung rechtmäßig, effizient, kooperativ, sparsam und bürgerfreundlich handelt.

3. Er beaufsichtigt die weiteren Träger öffentlicher Aufgaben, soweit nach Gesetz nicht der Kantonsrat zuständig ist.

Zgodnie z powyższym podmiot zaimkowy er w ustępie 2 i 3 jest z założenia referencjalnie tożsamy $\mathrm{z}$ podmiotem wyrażonym w ustępie pierwszym. Zaimki (anaforyczne) trzeciej osoby zastępują więc nazwy określające adresata normy i jednocześnie konstytuują relację strukturalną podmiot - podmiot. Ta sama reguła wyklucza użycie podmiotu zaimkowego poza obrębem jednego artykułu (paragrafu).

Analizując pod tym względem polskie i niemieckie teksty konstytucyjne, trzeba stwierdzić, że zasady te nie występują w technikach prac legislacyjnych tych krajów ${ }^{7}$. W niemieckiej ustawie zasadniczej można znaleźć tylko jeden przepis, w którym podmioty zaimkowe rozpoczynają kolejne ustępy. Jest to art. $60 \mathrm{GG}$ :

(1) Der Bundespräsident ernennt und entläßt die Bundesrichter, die Bundesbeamten, die Offiziere und Unteroffiziere, soweit gesetzlich nichts anderes bestimmt ist.

(2) Er übt im Einzelfalle für den Bund das Begnadigungsrecht aus.

(3) Er kann diese Befugnisse auf andere Behörden übertragen.

Generalnie zaimek osobowy jako równoważnik nazw określających podmiot stosuje się w zdaniach złożonych (zob. A. Malinowski 2012: 104). Zasadę tę stosuje się w legislacji wszystkich tu analizowanych systemów prawnych:

\footnotetext{
${ }^{5}$ Por. Richtlinien der Rechtsetzung (vom 21. Dezember 2005) Regierungsrat des Kantons Zürich, s. 1336, punkt 248 i 249. ,Jeder Paragraf bildet eine 'grammatikalische Einheit'; In ihm müssen und nur in ihm dürfen Relativpronomen verwendet werden, die auf vorgängig eingeführte Subjekte und Objekte Bezug nehmen. Oder umgekehrt: Grammatikalische Bezüge über die Paragrafen-Grenzen hinweg sind nicht zulässig““.

${ }^{6}$ Patrz też M. Nussbaumer (2007: 34).

${ }^{7}$ Por. Handbuch der Rechtsförmlichkeit. 3. Auflage, 2008. [Pobrano 14.06.2018].
} 
- $\quad$ art. 64. ust. 3. KRP: Wlasność może być ograniczona tylko w drodze ustawy i tylko w zakresie, w jakim nie narusza ona istoty prawa własności.

- $\quad$ art. 19 (3) GG: Die Grundrechte gelten auch für inländische juristische Personen, soweit sie ihrem Wesen nach auf diese anwendbar sind.

- $\quad$ art. 28 ust. 3 VCH: Streik und Aussperrung sind zulässig, wenn sie Arbeitsbeziehungen betreffen und wenn keine Verpflichtungen entgegenstehen, den Arbeitsfrieden zu wahren oder Schlichtungsverhandlungen zu führen.

Ponadto w przepisach niemieckich i szwajcarskich podmioty zaimkowe stosuje się wyłącznie w obrębie tego samego ustępu, jeżeli odnoszą się do podmiotu bezpośrednio poprzedzającego zdania. Por.

art. 40 (1) GG: Der Bundestag wählt seinen Präsidenten, dessen Stellvertreter und die Schriftführer. Er gibt sich eine Geschäftsordnung.

- $\quad$ art. 69 Konstytucji Kantonu Zurych: Der Regierungsrat handelt interkantonale und internationale Verträge aus. Er ist im Rahmen seiner Verordnungskompetenz allein für deren Abschluss zuständig.

W polskich aktach legislacyjnych taki szyk podmiotu zaimkowego nie wyst ępuje, ponieważ pierwsza i ostatnia pozycja w zdaniu wyrażającym normę prawną jest pozycją akcentowaną. Zgodnie z tym na początku lub końcu zdania umieszcza się te człony zdania, które uznaje się za najbardziej istotne i dlatego nie powinny być zajmowane przez wyrazy mało istotne lub semantycznie niesamodzielne (zob. H. Jadacka 1995: 158; A. Malinowski 2012: 115). Przekład syntagmatyczny z zachowaniem szyku podmiotu zaimkowego w zdaniu wyjściowym może nadać mu bowiem sens, którego nie ma w tekście wyjściowym ${ }^{8}$. Pozycją neutralną dla podmiotu zaimkowego w języku polskim jest miejsce za orzeczeniem, jak w art. 93. ust. $2 \mathrm{KRP}$ :

Zarządzenia są wydawane tylko na podstawie ustawy. Nie mogą one stanowić podstawy decyzji wobec obywateli, osób prawnych oraz innych podmiotów.

\section{Frekwencja podmiotów zaimkowych w aktach prawnych}

Z własnych badań frekwencji podmiotów zaimkowych (on, ona, one) wynika, że w tekście polskiej konstytucji użyto ich łącznie 11 razy $^{9}$. Jest to frekwencja minimalna. Dla porównania w Konstytucji Kantonu Zurych zaimek osoby trzeciej w funkcji podmiotu występuje 78 razy, w konstytucji szwajcarskiej 220 razy i niemieckiej 99 razy $^{10}$. Natomiast obszerne analizy Mikołajczaka wykazały, że zdań z podmiotem zaimkowym w polskich ustawach jest zaledwie 2\% (zob. S. Mikołajczak 1994: 44). Również Zieliński dostrzega dużą rezerwę redaktorów tekstów prawnych do stosowania anafory składniowej w tekstach prawnych (zob. M. Zieliński 1999: 56). Występuje

\footnotetext{
${ }^{8} \mathrm{Na}$ przykład zaimek on na pozycji akcentowanej implikowałby znaczenie „to właśnie ON, a nie kto inny".

${ }^{9}$ Inne zaimki rzeczowne, jak np. każdy, wykazują znacznie wyższą frekwencję w tekście polskiej konstytucji.

${ }^{10}$ Relatywnie wysoka liczba podmiotów zaimkowych w niemieckiej ustawie zasadniczej jest konsekwencją wielozdaniowych akapitów. Podmioty w kolejnych zdaniach z tożsamą funkcją referencyjną mają z reguły formę zaimka osobowego trzeciej osoby, tak jak np. w cytowanym wyżej art. $40 \mathrm{GG}$.
} 
ona jedynie w obrębie danego przepisu, niekoniecznie w zdaniach wyst ępujących bezpośrednio po sobie.

Niska frekwencja podmiotów zaimkowych jest zatem typową cechą polskich aktów prawnych. Preferencja podmiotów rzeczownikowych w polskim prawodawstwie jest motywowana zapewne tym, że każdą jednostkę tekstu prawnego cechuje duża niezależność treściowa, umożliwiająca jej samodzielne funkcjonowanie poza danym aktem prawnym. Konsekwencją takiej autonomii jest niezależność gramatyczna i znaczeniowa poszczególnych wypowiedzeń aktu prawnego oraz restrykcje w stosowaniu w nich środków spójnościowych (zob. M. Zieliński 1999: 56) ${ }^{11,12}$. Dzięki temu przepisy prawne można cytować pojedynczo i w oderwaniu od ich kontekstu. Z tego względu formułuje się je z reguły bez podmiotów zaimkowych.

\section{Podmiot domyślny w polskich aktach prawnych}

Specyficzną własnością składni polskiej jest możliwość występowania podmiotów domyślnych, czyli niewyrażonych wprost. W tekstach literackich ich frekwencja wynosi 30\%, natomiast w tekstach ustaw zaledwie 0,5\% (zob. S. Mikołajczak 1994: 44). W zdaniach niemieckich nie ma podmiotów domyślnych, ponieważ podmiot w strukturze powierzchniowej jest obligatoryjny (zob. G. Helbig/ J. Buscha 1984: 544). Natomiast w zdaniach złożonych współrzędnie łącznie możliwa jest redukcja podmiotu podobnie jak w języku polskim ${ }^{13}$. Por.:

- $\quad$ art. 110. ust. 2. KRP: Marszałek Sejmu przewodniczy obradom Sejmu, strzeże praw Sejmu oraz reprezentuje Sejm na zewnątrz.

- $\quad$ art. 7 ustęp 4 GG: (4) [...] Private Schulen als Ersatz für öffentliche Schulen bedürfen der Genehmigung des Staates und unterstehen den Landesgesetzen.

Elipsa podmiotu usuwa nadmiar powtórzeń w tekście i jest wyrazem spójności i ekonomii języka. Połączenie kilku zdań w jednym zdaniu złożonym wskazuje na szczególną łączność i kumulację wyszczególnionych w nich faktów. Mimo to podmiot domyślny w tekstach prawnych pojawia się sporadycznie i w zasadzie tylko w zdaniach złożonych (zob. M. Zeifert 2015: 102). Zgodnie z powyższym podmiot domyślny $w$ polskim tekście konstytucji jest zjawiskiem raczej wyjątkowym, stosowanym najczęściej w zdaniach współrzędnie złożonych łącznie lub z enumeratywnie wymienianymi orzeczeniami, w których przecinek pełni funkcję spójnika (zob. Z. Saloni/ M. Świdziński 1998: 67) jak w art. 148. KRP:

\section{Prezes Rady Ministrów:}

1) reprezentuje Radę Ministrów,

2) kieruje pracami Rady Ministrów,

\footnotetext{
${ }^{11}$ Do gramatycznych środków spójnościowych zalicza się m.in. zaimki i podmiot domyślny.

${ }^{12}$ Repetycje tych samych składników leksykalnych w opinii K. Stępniaka (2018: 89) są zjawiskiem nagminnym w tekście Konstytucji RP i świadczą o pewnej nieporadności językowej ustawodawcy. W wielu przepisach nie spełniają bowiem wymogu komunikatywności tekstu prawnego, a ich stosowanie nie podkreśla doniosłości języka użytego w danym akcie.

${ }^{13}$ Zgodnie z regułami gramatycznymi w polskich zdaniach współrzędnie złożonych nie oznacza się podmiotu w kolejnych zdaniach składowych. Skoro nie jest on wyrażony wprost, należy go traktować jako podmiot domyślny.
} 
3) wydaje rozporządzenia,

4) zapewnia wykonywanie polityki Rady Ministrów i określa sposoby jej wykonywania,

5) koordynuje i kontroluje pracę członków Rady Ministrów,

6) sprawuje nadzór nad samorządem terytorialnym w granicach i formach określonych w Konstytucji i ustawach,

7) jest zwierzchnikiem służbowym pracowników administracji rządowej.

\section{Systemowe różnice interlingwalne w zakresie formy i szyku podmiotu zaimkowego}

Omówione różnice można ująć w następujący sposób:

- Obecność podmiotu w zdaniach niemieckojęzycznych jest z reguły obligatoryjna, w polskich zdaniach pojedynczych może wystąpić tzw. podmiot domyślny, czyli niewyrażony wprost.

- Polskie reguły składniowe ograniczają użycie podmiotu zaimkowego przed orzeczeniem. W języku niemieckim takich ograniczeń nie ma. Co więcej, szwajcarskie zasady techniki legislacyjnej zalecają wręcz jego użycie na początku zdania ze względu na większą jasność i czytelność normy prawnej.

- Szyk podmiotu w języku niemieckim jest ściśle określony, w języku polskim bardziej swobodny, chociaż niedowolny.

- Podmioty zaimkowe w polskich aktach prawnych wykazują minimalną frekwencję. Częstość ich użycia w aktach niemieckojęzycznych jest znacząco wyższa.

- Typowym szykiem w zdaniu normatywnym jest układ temat - remat, przy czym temat $\mathrm{z}$ reguły identyfikuje adresata normy wyrażonego w podmiocie (zob. A. Malinowski 2012: 195). Jeśli szyk zdania jest inny, to na pierwszym miejscu pojawia się ten człon, który jest ,,nośnikiem zasadniczego ustalenia w danym ustępie czy punkcie" (zob. S. Mikołajczak 1994: 47). Arbitralne przekształcenie szyku podmiotu w tekście docelowym zmienia zatem nie tylko konsekwentnie stosowany schemat konstrukcyjny w wyjściowym porządku prawnym, lecz także może zniekształcić odniesienia tematyczno-rematyczne w tekście docelowym. W takiej sytuacji modyfikacja szyku lub jego niedostosowanie do wymogów języka docelowego może naruszyć schemat odbioru zdania, zwłaszcza jeśli jest on utrwalony w danej kulturze prawnej.

- Miejscami o szczególnym znaczeniu strategicznym w języku polskim są pierwsza i ostatnia pozycja w zdaniu. Jest ona zarezerwowana dla informacji najważniejszych (zob. H. Jadacka 1995: 158). Modyfikacja szyku może więc powodować niezamierzoną zmianę elementu komunikacyjnie znaczącego.

Wskazane wyżej różnice systemowe wymagają więc szczególnej uwagi tłumacza i przemyślanego wyboru strategii przekładu.

\section{Strategie przekładu podmiotów zaimkowych}

W celu eksplikacji problemów translacyjnych posłużymy się przykładami zaczerpniętymi z opublikowanych przekładów tekstów konstytucji szwajcarskiej 
(VCH), niemieckiej (GG) i polskiej (KRP). Dla przykładu artykuł $2 \mathrm{VCH}$ :

1. Die Schweizerische Eidgenossenschaft schützt die Freiheit und die Rechte des Volkes und wahrt die Unabhängigkeit und die Sicherheit des Landes.

2. Sie fördert die gemeinsame Wohlfahrt, die nachhaltige Entwicklung, den inneren Zusammenhalt und die kulturelle Vielfalt des Landes.

3. Sie sorgt für eine möglichst große Chancengleichheit unter den Bürgerinnen und Bürgern.

4. Sie setzt sich ein für die dauerhafte Erhaltung der natürlichen Lebensgrundlagen und für eine friedliche und gerechte internationale Ordnung.

składa się z czterech ustępów, przy czym w ustępie 1 podmiot został wyrażony wyrażeniem nominalnym, w kolejnych - godnie z zasadami szwajcarskiej legislacji - ma formę zaimka osobowego w mianowniku. W przekładzie tego artykułu na język polski podmioty zaimkowe zostały wyzerowane ${ }^{14}$. Identyfikację podmiotu domyślnego umożliwiają końcówki fleksyjne czasowników. Por.

1. VCH: Konfederacja Szwajcarska chroni wolności i prawa narodu oraz strzeże niezawisłości i bezpieczeństwa kraju.

2. Wspiera ogólny dobrobyt [...].

3. Troszczy się o jak największą równość [...].

4. Angażuje się na rzecz trwałego zachowania naturalnych warunków życia [...]. W przekładzie artykułu $64 \mathrm{VCH}$ :

1. Der Bund fördert die wissenschaftliche Forschung und die Innovation.

2. Er kann die Förderung insbesondere davon abhängig machen, dass die Qualitätssicherung und die Koordination sichergestellt sind.

3. Er kann Forschungsstätten errichten, übernehmen oder betreiben.

zachowano podmiot zaimkowy, dostosowując jego szyk do reguł języka polskiego ${ }^{15}$.

1. Federacja popiera badania naukowe.

2. Może ona uzależnić swoje poparcie od zabezpieczenia koordynacji.

3. Może ona zakładać, przejmować i prowadzić palcówki badawcze.

Jak widać na podstawie przytoczonych przykładów, tłumacz w analogicznych sytuacjach zastosował dwie różne strategie przekładu.

W polskojęzycznej wersji niemieckiej ustawy zasadniczej problem przekładu podmiotów wyrażonych zaimkiem osobowym w trzeciej osobie rozwiązano za pomocą takiej zmiany szyku wyrazów, która umożliwia elipsę podmiotu ${ }^{16}$. Na przykład ww. art. 60 UZ/B\&M ustęp 2 i 3 zmieniono szyk wyrażeń $w$ indywidualnych przypadkach i powyższe uprawnienia, przenosząc je przed orzeczenie. Ponadto w ustępie 2 wyzerowano podmiot zaimkowy, a w kolejnym zachowano go, mimo że odniesienia referencyjne są jednoznaczne.

Por. treść art. $60 \mathrm{GG}$ ust. 2 i $3 \mathrm{z}$ ich przekładami:

(2) Er übt im Einzelfalle für den Bund das Begnadigungsrecht aus.

(3) Er kann diese Befugnisse auf andere Behörden übertragen.

\footnotetext{
${ }^{14}$ Por. Z. Czeszejko-Sochacki (2000), Konstytucja szwajcarska. Warszawa, s. 42.

15 Tamże, s. 64.

16 Por. Ustawa Zasadnicza Republiki Federalnej Niemiec w tłumaczeniu B. Banaszaka i A. Malickiej.
} 
Przekład art. $60 \mathrm{UZ}$ przez Banaszaka i Malicką:

(1) Prezydent Federalny mianuje i odwołuje sędziów federalnych, urzędników federalnych, oficerów i podoficerów, jeżeli ustawa nie stanowi inaczej.

(2) W indywidualnych przypadkach stosuje w imieniu Federacji prawo łaski.

(3) Powyższe uprawnienia może on przekazać innym władzom. W przekładzie Sadowskiego te samy ustępy mają następującą formę:

(2) Wykonuje w indywidualnych przypadkach prawo łaski w imieniu Federacji.

(3) Uprawnienia te może przekazać innym organom władzy.

Jak widać, w obu ustępach wyzerowano podmiot zaimkowy, raz zmieniono szyk dopełnienia, a raz zachowano szyk tekstu wyjściowego.

W przekładzie tych samych ustępów przez Schwierskott zachowano podmiot zaimkowy i nie zmieniono szyku wyrazów przed orzeczeniem. Por.:

(2) Wykonuje on w pojedynczych wypadkach w imieniu Federacji prawo łaski.

(3) Może on przekazać swoje kompetencje innym urzędom.

Podane przykłady potwierdzają, że różne rozwiązania przekładu tego samego podmiotu zaimkowego podejmowane są nawet w obrębie jednego artykułu. Ponadto arbitralna zmiana szyku w translacie może jednak zniekształcić strukturę tematycznorematyczną tekstu wyjściowego. W języku polskim dotyczy to zwłaszcza pierwszej i ostatniej pozycji zdania (zob. H. Jadacka 1995: 158).

Elipsę niemieckiego podmiotu zaimkowego w przekładzie na język polski stosuje się niezależnie od tego, czy dany podmiot występuje w zdaniu złożonym, czy rozpoczyna kolejne zdanie.

Por. art 67 (1) GG:

Der Bundestag kann dem Bundeskanzler das Mißtrauen nur dadurch aussprechen, daß er mit der Mehrheit seiner Mitglieder einen Nachfolger wählt und den Bundespräsidenten ersucht, den Bundeskanzler zu entlassen.

Przekład tego artykułu w UZ/B\&M:

Bundestag może wyrazić Kanclerzowi Federalnemu wotum nieufności tylko w ten sposób, że głosami większości swoich członków dokona wyboru jego następcy i zwróci się do Prezydenta Federalnego z wnioskiem o odwołanie Kanclerza Federalnego.

W tym samym artykule w thumaczeniu Sadowskiego podmiot zaimkowy został zachowany, drugi raz opuszczony. Por.:

Bundestag może wyrazić Kanclerzowi Federalnemu wotum nieufności tylko w taki sposób, że wybierze on głosami większości ustawowej liczby deputowanych następcę i przedłoży Prezydentowi Federalnemu wniosek o odwołanie dotychczasowego kanclerza.

Inny przykład; art. $45 \mathrm{GG:}$

Der Bundestag bestellt einen Ausschuß für die Angelegenheiten der Europäischen Union. Er kann ihn ermächtigen, die Rechte des Bundestages gemäß Artikel 23 gegenüber der Bundesregierung wahrzunehmen. Er kann ihn auch ermächtigen, die Rechte wahrzunehmen, die dem Bundestag in den vertraglichen Grundlagen der Europäischen Union eingeräumt sind. 
W przekładzie tego artykułu we wszystkich tłumaczeniach niemiecki podmiot zaimkowy przed orzeczeniem został konsekwentnie wyzerowany. Por.:

Bundestag powołuje Komisję do spraw Unii Europejskiej. Może ją upoważnić do wykonywania wynikających z art. 23, praw Bundestagu wobec Rządu Federalnego. Może ją także upoważnić do korzystania z praw przyznanych Bundestagowi i Bundesratowi w traktatach założycielskich Unii Europejskiej.

Z perspektywy stylistycznych norm języka ogólnego zastosowane rozwiązanie translacyjne jest poprawne, chociaż w polskich tekstach prawnych mało uzualne.

\section{Przekład podmiotu zaimkowego i domyślnego na język niemiecki}

Ze względu na niską frekwencję podmiotu zaimkowego i domyślnego w polskiej Konstytucji jego przekład nie jest tak problematyczny, zwłaszcza że reguły ich użycia lub wyzerowania w zdaniach złożonych współrzędnie łącznie w języku polskim i niemieckim są analogiczne. Syntagmatyczne tłumaczenia polskich przepisów konstytucyjnych na ten język zachowują z reguły strukturę tekstu wyjściowego.

Por. art. 133 ust. 1 KRP:

1. Prezydent Rzeczypospolitej jako reprezentant państwa w stosunkach zewnętrznych:

1) ratyfikuje i wypowiada umowy międzynarodowe, o czym zawiadamia Sejm i Senat,

2) mianuje i odwołuje pełnomocnych przedstawicieli Rzeczypospolitej Polskiej w innych państwach i przy organizacjach międzynarodowych,

3) przyjmuje listy uwierzytelniające i odwołujące akredytowanych przy nim przedstawicieli dyplomatycznych innych państw i organizacji międzynarodowych.

Por. syntagmatyczne tłumaczenie tego przepisu dokonanego przez Misior:

1. Der Präsident der Republik Polen als Vertreter des Staates in äußeren Beziehungen

1) ratifiziert und kündigt völkerrechtliche Verträge, wovon er dem Sejm und dem Senat Mitteilungen macht,

2) ernennt bevollmächtigte Vertreter der Republik Polen in anderen Staaten und bei internationalen Organisationen und beruft sie ab,

3) akzeptiert Beglaubigungs- und Abberufungsschreiben der bei ihm akkreditierten diplomatischen Vertreter anderer Staaten und internationaler Organisationen.

Przekład tego samego artykułu przez Schwierskott:

Der Präsident der Republik Polen vertritt die Republik Polen in auswärtigen

Beziehungen ${ }^{17}$ und

\footnotetext{
${ }^{17}$ Przytoczony przekład art. 133, ust. 1 pkt. 1 jest nieadekwatny w stosunku do tekstu wyjściowego zarówno pod względem formalnym jak i treściowym. W ustępie 1 dodano orzeczenie vertritt (reprezentuje), którego nie ma w tekście wyjściowym. Ponadto w przekładzie zniekształcono konstrukcję tego artykułu w taki sposób, że wyjściowa struktura enumeratywna została zamieniona na zdanie złożone współrzędne łączne.
} 
1) ratifiziert und kündigt völkerrechtliche Verträge und unterrichtet darüber den Sejm und den Senat,

2) ernennt und entlässt bevollmächtigte Gesandte der Republik Polen in anderen Staaten und bei internationalen Organisationen,

3) empfängt Beglaubigungs- und Entlassungsschreiben der bei ihm akkreditierten Gesandten anderer Staaten und internationaler Organisationen.

W przekładzie innych artykułów zmieniano strukturę ustępu w taki sposób, że zdanie wielokrotnie złożone współrzędnie łącznie zostało podzielone arbitralnie na dwa odrębne zdania. Zmiana ta wymusiła w utworzonym zdaniu dodanie dwóch podmiotów zaimkowych. W ten sposób naruszono regułę kropki, tzn. jednemu zdaniu oryginału musi odpowiadać jedno zdanie w przekładzie.

Por. art. 5. KRP:

Rzeczpospolita Polska strzeże niepodległości i nienaruszalności swojego terytorium, zapewnia wolności i prawa człowieka i obywatela oraz bezpieczeństwo obywateli, strzeże dziedzictwa narodowego oraz zapewnia ochronę środowiska, kierując się zasadą zrównoważonego rozwoju.

i jego przekład dokonany przez Schwierskott:

Die Republik Polen wacht über die Unabhängigkeit und die Unverletzlichkeit ihres Territoriums, gewährleistet die Freiheiten und die Rechte des Menschen und des Staatsbürgers sowie die Sicherheit des Bürgers. Sie wacht über das nationale Erbe und gewährleistet den Umweltschutz, wobei sie sich nach dem Grundsatz der Ausgewogenheit richtet.

Ten sam artykuł w tłumaczeniu E. Misior zachowuje strukturę tekstu wyjściowego ${ }^{18}$. Die Republik Polen schützt die Unabhängigkeit und Integrität ihres Territoriums, gewährleistet Freiheiten und Rechte der Menschen und der Bürger sowie die Sicherheit der Staatsbürger, schützt das nationale Erbe und gewährleistet den Umweltschutz, wobei sie sich von dem Prinzip der gleichmäßigen Entwicklung leiten läßt.

\section{Propozycje przekładu podmiotu zaimkowego z zachowaniem ekwiwalencji tekstowonormatywnej (stylistycznej)}

Zachowanie podmiotu zaimkowego w zdaniach pojedynczych jak i przekład udamawiający, polegający na jego wyzerowaniu, jest wprawdzie zgodny z zasadami gramatyki języka ogólnego, ale nie odpowiada normom składniowym polskich aktów prawnych. W takiej sytuacji należałoby rozważyć, czy lepszym rozwiązaniem byłby przekład, w którym podmiot zaimkowy w zdaniach pojedynczych jest tłumaczony za pomocą nazwy, na którą wskazuje w poprzednim wypowiedzeniu.

Por. wyżej cytowany art. $64 \mathrm{VCH}$ :

1. Federacja popiera badania naukowe.

2. Federacja może uzależnić swoje poparcie od zabezpieczenia koordynacji.

3. Federacja może zakładać, przejmować i prowadzić palcówki badawcze.

\footnotetext{
${ }^{18}$ Inne różnice w zakresie doboru leksyki pozostają poza ramami niniejszej analizy.
} 
Rozważane rozwiązanie odpowiada stylowi polskich aktów normatywnych, w których preferuje się powtórzenia dosłowne zamiast zaimków osobowych. Według zaleceń Kodeksu (2005: 87) „[p]oszanowanie konwencji poszczególnych rejestrów wyklucza możliwość tłumaczenia dosłownego i literalnego tekstów specjalistycznych, które na poziomie całego tekstu wymagają zawsze tłumaczenia transpozycyjnego". Ponadto proponowane podejście koresponduje z generalną koncepcją przekładu Nidy i Tabera, w której podkreśla się konieczność zachowania ekwiwalencji na poziomie pojęciowym i stylistycznym, oraz z zasadą eksplicytacji (zob. E. Nida/ Ch. Taber 1969: 12). Ta ostatnia polega na wyrażeniu w tekście docelowym informacji semantycznej, która „nie jest zawarta w strukturze powierzchniowej tekstu źródłowego, niemniej jest wyrażana w sposób implicytny i wynika z kontekstu kognitywnego" (zob. K. Kaczmarek/ A. Matulewska 2008: 89). Zastąpienie zaimka powtórzeniami referencyjnie tożsamego rzeczownika jest jedną ze strategii eksplicytacyjnej wymienianej w literaturze przedmiotu (zob. E. Gumul 2011: 14). Jej świadome stosowanie ma na celu optymalizację zrozumienia treści przełożonego tekstu ${ }^{19}$. Jest to istotne w sytuacjach, w których zaimkowe odniesienia anaforyczne są jednoznaczne w tekście wyjściowym, natomiast w tekście docelowym mogą być niejasne ze względu na inny rodzaj lub liczbę rzeczownika i korespondującego z nim zaimka, który w translacie może mieć więcej odniesień niż w tekście wyjściowym.

Por. art. 70 Konstytucji Kantonu Zurych:

1. Der Regierungsrat leitet die kantonale Verwaltung und bestimmt im Rahmen des Gesetzes ihre Organisation.

2. Er sorgt dafür, dass die Verwaltung rechtmäßig, effizient, kooperativ, sparsam und bürgerfreundlich handelt.

3. Er beaufsichtigt die weiteren Träger öffentlicher Aufgaben, soweit nach Gesetz nicht de Kantonsrat zuständig ist.

W zacytowanym artykule odniesienia anaforyczne zaimka er są jednoznaczne. Ponadto szwajcarskie i kantonalne reguły legislacyjne wskazują, jak w wątpliwych sytuacjach należy odczytywać te odniesienia. Tak więc wiedza o nich ułatwia zadanie interpretacyjne. W przekładzie tegoż artykułu na język polski:

1. Rząd Kantonalny kieruje administracją kantonalną i w ustawowych ramach określa jej organizację.

2. Ma na względzie, by administracja działała zgodnie z prawem, efektywnie, z otwartością na współpracę, oszczędnie i życzliwie wobec obywateli.

3. Nadzoruje on dalsze podmioty zadań publicznych, o ile stosownie do ustawy nie jest właściwy Sejm Kantonalny.

w ustępie 2 nie ma niejasności co do tego, kto kogo nadzoruje. Natomiast w ustępie 3 powstają już wątpliwości interpretacyjne. Można się bowiem zastanawiać, kto ma funkcję nadzorczą: rząd z punktu pierwszego czy administracja z drugiego? W tym

\footnotetext{
${ }^{19}$ Mając na uwadze powyższe, nasuwa się uzasadnione pytanie, dlaczego przekład z wyzerowaniem niemieckiego podmiotu zaimkowego powiązany ze zmianą szyku ma być uznany za bardziej akceptowalny niż strategia eksplicytacji, która w analizowanym przypadku adekwatniej spełnia wymagania stylowe języka prawnego.
} 
przypadku przekład z eksplicytnie wyrażonym podmiotem ujednoznacznia właściwą relację anaforyczną.

Inna możliwość przekładu polegałaby na zachowaniu struktury i sposobu zespolenia elementów jak w artykule 133 ust. 1 Konstytucji RP i jego wyżej podanym przekładzie. $\mathrm{W}$ proponowanym rozwiązaniu enumerowane ustępy nie byłyby oddzielone kropkami, lecz tzw. przecinkami spójnikowymi. W ten sposób przełożony artykuł 64 VCH zachowałby strukturę zdania współrzędnie złożonego łącznie i jednocześnie mikrostrukturę artykułu tekstu wyjściowego. Por.:

1. Federacja popiera badania naukowe,

2. może uzależnić swoje poparcie od zabezpieczenia koordynacji,

3. może zakładać, przejmować i prowadzić palcówki badawcze.

Oba rozwiązania są zgodne z uzusem składniowym i stylem polskich aktów normatywnych. W zaproponowanej formie cechuje je absolutna jednoznaczność. Poza tym dyskutowane rozwiązania translacyjne spełniają kryteria stosowania strategii thumaczenia udomawiającego, ponieważ dotyczą wyłącznie kwestii formalnych, w tym przypadku językowego sposobu określenia adresata przepisu (zob. E. Wiesmann 1999: 174-175).

\section{Wnioski}

Zachowanie podmiotu zaimkowego lub jego wyzerowanie w przekładzie syntagmatycznym na język polski jest wprawdzie możliwe, ale w tekstach prawnych - jak to wynika z wyżej przytoczonych powodów i danych statystycznych - mało uzualne. W polskich aktach prawnych nie używa się ich bowiem w zdaniach pojedynczych, natomiast w zdaniach złożonych występują sporadycznie i wyłącznie w kontekstach jednoznacznych.

Wiedza o specyfice składni aktów prawnych jest ważnym elementem warunkującym adekwatne zrozumienie oraz językowo i merytorycznie poprawny przekład tekstów prawnych ${ }^{20}$. Jak to zostało wykazane wyżej, bez gruntownej wiedzy decyzje translacyjne podejmowane są arbitralnie i niekonsekwentnie. Często naruszają nie tylko obowiązujące normy redakcyjne w języku docelowego systemu prawnego, lecz także treść tłumaczonego przepisu. Kompetencja translacyjna powinna zatem obejmować wiedzę nie tylko o regułach składniowych języka ogólnego, lecz również o specyficznych regułach redakcyjnych aktów prawnych obowiązujących w danym porządku prawnym.

Na podstawie analizowanego materiału wykazano wyraźną kolizję strategii przekładu źródłopodobnego z zalecanymi zasadami tłumaczenia tekstów prawych w Kodeksie tłumacza przysięgłego. Jak się okazuje, ważnym czynnikiem ułatwiającym podjęcie konkretnej decyzji translacyjnej jest frekwencja korespondujących form gramatycznych w dwóch różnych językach (zob. Ł. Iluk 2018). Jej konsekwentne

${ }^{20}$ Więcej na temat znaczenia wiedzy o języku prawa w procesie translacyjnym w Ł. Iluk (2017). 
uwzględnienie gwarantuje przekład, który będzie bardziej odpowiadał uzusowi języka docelowego porządku prawnego ${ }^{21}$.

Przedstawione wyniki analizy potwierdzają słuszność poglądu wysuniętego przez F. Gruczę (2018: 8), że bazowa translatoryka poznawcza dostarcza odpowiedniej wiedzy empirycznej i aplikatywnej dotyczącej rozwiązań w zakresie prawidłowego przekładu wybranych tekstów prawnych zgodnie z ich specyfiką i obowiązującymi normami preskryptywnymi w języku docelowego systemu prawnego.

\section{Bibliografia}

Gizbert-Studnicki, T. (2001), Problem przekładu tekstów prawnych, (w:) „Dziedzictwo prawne XX wieku. Księga pamiątkowa z okazji 150-lecia TBSP UJ". Zakamycze, 41-55.

Grucza, F. (2018), O przedmiocie i zadaniach translatoryki raz jeszcze, (w:) „Applied Linguistics Papers" 25/4, 1-14.

Gumul, E. (2011), Eksplicytacja w ttumaczeniu symultanicznym, (w:) P. Janikowski (red.), Z zagadnień dydaktyki tłumaczenia ustnego. Częstochowa, 11-31.

Helbig, G./ J. Buscha (1984), Deutsche Grammatik. Leipzig.

Iluk, Ł. (2017), Wiedza o języku prawnym w kształceniu tłumaczy tekstów prawnych i prawniczych, (w:) ,Studia Niemcoznawcze” LIX, 527-544.

Iluk, Ł. (2018), Lokalizator temporalny data $w$ polskim prawie procesowym i jego odpowiedniki w języku niemieckim, (w:) ,Studia Niemcoznawcze” LXI, 817-833.

Jadacka, H. (1995), Język naszych ustaw. III. O kolejności wyrazów w zdaniu polskim, (w:) „Biuletyn Rady Legislacyjnej. Przegląd Legislacyjny” 5, 157-169.

Kaczmarek, K./ A. Matulewska (2008), Wykładnia normy prawnej a metodologia przekładu, (w:) „Rocznik Przekładoznawczy” 3/4, 81-94.

Kodeks tłumacza przysięglego z komentarzem (2005). Warszawa.

Malinowski, A. (2012), Polski tekst prawny. Opracowanie treściowe i redakcyjne. Wydanie 3. Warszawa.

Mikołajczak, S. (1994), Składnia współczesnych ustaw sejmowych, (w:) Z. Zagórski (red.), Język a współczesne społeczeństwo polskie. Poznań, 37-48.

Nida, E./ Ch. Taber (1969), The Theory and Practice of Translation. Leiden.

Nussbaumer, M. (2007), Gesetzestext und Wissenstransfer? - Welche Funktionen Gesetzestexte erfüllen müssen und wie man sie optimieren kann, (w:) D. Heller/ K. Ehlich (Hrsg.), Studien zur Rechtskommunikation. Berlin i in., 17-46.

Saloni, Z./ M. Świdziński (1988), Składnia współczesnego języka polskiego. Wydanie 4. Warszawa.

Stępniak, K. (2018), Nadmiarowość językowa w Konstytucji RP z 1997 roku, (w:) „Przegląd Sejmowy” 5(148), 76-93.

Wiesmann, E. (1999), Berücksichtigung von Textsortenkonventionen bei der Übersetzung von Rechtstexten am Beispiel der Übersetzung italienischer Atti di citazione

${ }^{21} \mathrm{Na}$ przeszkody translacyjne związane z odmienną stylistyką tekstów prawnych i prawniczych wskazuje również T. Gizbert-Studnicki (2001: 45). 
ins Deutsche, (w:) P. Sandrini (Hrsg.), Übersetzen von Rechtstexten. Fachkommunikation im Spannungsfeld zwischen Rechtsordnung und Sprache. Tübingen, 155-182.

Zeifert, M. (2015), Podmiotowość zaklęta $w$ języku - analiza podmiotu $w$ strukturze składniowej zdań języka prawnego, (w:) A. Bielska-Brodziak (red.), O czym mówią prawnicy, mówiąc o podmiotowości. Katowice, 97-115.

Zieliński, M. (1999), Języki prawne i prawnicze, (w:) W. Pisarek (red.), Polszczyzna 2000. Orędzie o stanie języka na przełomie tysiącleci. Kraków, 50-74.

\section{Akty prawne}

Bundesverfassung der Schweizerischen Eidgenossenschaft vom 18. April 1999 (Stand am 1. Januar 2018). Cyt. VCH.

Konstytucja federalna Konfederacji Szwajcarskiej z dnia 18 kwietnia 1999 r. Tłumaczenie Z. Czeszejko-Sochacki, (2000), Warszawa. Cyt. VCH.

Grundgesetz für die Bundesrepublik Deutschland vom 23. Mai 1949 (BGB1. S. 1), zuletzt geändert durch Artikel 1 des Gesetzes vom 13. Juli 2017 (BGBl. I S. 2347). Cyt. GG.

Handbuch der Rechtsförmlichkeit. 3. Auflage, 2008.

Konstytucja Rzeczypospolitej Polskiej z dnia 2 kwietnia 1997 r. Dz.U. 1997 nr 78 poz. 483. Cyt. KRP.

Leitfaden für die Ausarbeitung von Erlassen des Bundes. Bundesamt für Justiz 2007. Ziffer 8235 (888), s. 359. Cyt. Gesetzgebungsleitfaden 2007.

Richtlinien der Rechtsetzung (vom 21. Dezember 2005). Regierungsrat des Kantons Zürich. Cyt. Richtlinien Zürich.

Rozporządzenie Prezesa Rady Ministrów z dnia 20 czerwca 2002 r. w sprawie "Zasad techniki prawodawczej". Dz. U. Nr 100, poz. 908. Cyt. ZTP.

Ustawa Zasadnicza Republiki Federalnej Niemiec z dnia 23 maja 1949. Stan na 21 lipca 2010. Tłumaczenie Bogusław Banaszak i Agnieszka Malicka. [Pobrano 15.06.2018]. Cyt. UZ/B\&M.

Ustawa Zasadnicza dla Republiki Federalnej Niemiec. Tekst bez komentarza. Stan: październik 2010 r. Tłumaczenie Aleksander-Marek Sadowski. [Pobrano 15.06.2018]. Cyt. UZ/Sa.

Ustawa Zasadnicza Republiki Federalnej Niemiec z 23 maja 1949 r. zmieniona $w$ dniu 29 lipca 2009 r. (BGBl. I S. 2248). Tłumaczenie z języka niemieckiego Ewa Schwierskott-Matheson. [Pobrano 15.06.2018]. Cyt. UZ/Sch.

Verfassung der Republik Polen vom 2. April 1997. Tłumaczenie Ewa Schwierskott. [Pobrano 20.06.2018]. Cyt. VRP/Sch.

Verfassung der Republik Polen vom 2. April 1997. Tłumaczenie Ewa Misior. [Pobrano 20.06.2018]. Cyt. VRP/M.

Verfassung des Kantons Zürich (vom 27. Februar 2005). [Pobrano 25.06.2018]. Cyt. VKZ. 